Research Article

\title{
Gas Exchange and Productivity in Temperate and Droughty Years of Four Eastern, Elite Loblolly Pine Genotypes Grown in the Western Gulf Region
}

\author{
Michael A. Blazier $\mathbb{D}^{1},{ }^{1}$ Michael C. Tyree $\mathbb{D}^{2,3}$ Mary Anne Sword Sayer, ${ }^{4}$ Dipesh KC, \\ Wilson G. Hood, ${ }^{3}$ and Bradley S. Osbon ${ }^{1}$ \\ ${ }^{1}$ Louisiana State University AgCenter, Hill Farm Research Station, Homer, LA 71040, USA \\ ${ }^{2}$ Department of Biology, Indiana University of Pennsylvania, Indiana, PA 15705, USA \\ ${ }^{3}$ Work performed while at: School of Forestry, Louisiana Tech University, P.O. Box 10138, Ruston, LA 71272, USA \\ ${ }^{4}$ USDA Forest Service, Southern Research Station, Pineville, LA 71360, USA
}

Correspondence should be addressed to Michael A. Blazier; mblazier@agcenter.lsu.edu

Received 21 June 2018; Revised 21 October 2018; Accepted 11 November 2018; Published 3 December 2018

Guest Editor: Arun Lahiri Majumder

Copyright (c) 2018 Michael A. Blazier et al. This is an open access article distributed under the Creative Commons Attribution License, which permits unrestricted use, distribution, and reproduction in any medium, provided the original work is properly cited.

\begin{abstract}
Loblolly pine plantations in the western portion of the species' range are sometimes planted with genotypes from the eastern portion of its range to improve plantation productivity. Advances in loblolly pine breeding have led to the development of clonally propagated genotypes with higher potential growth rates and better form than more commonly planted half-sib genotypes. At a site in the western portion of the loblolly pine range, four genotypes from the eastern portion of the loblolly pine range were established. Two genotypes (HS756 and HS8103) were half-sib, and two genotypes (V9 and V93) were varieties. The V93 genotype was propagated from the HS756 genotype. The objective of this study was to determine the effects of genotype on seasonal trends in gas exchange parameters at the leaf and crown levels, growth, and biomass allocation patterns. During the two-year study, one year had precipitation and temperature trends similar to the long-term average and one year had extreme drought, with record heat. The HS756, V9, and V93 genotypes had the highest height growth throughout the study. The V93 genotype was sensitive to the drought; its leaf- and crown-level $A_{\text {sat }}$ and $g_{s}$, declined during the drought more markedly than those of the other genotypes. Although its $A_{\text {sat }}$ and $g_{s}$ were affected by drought, height growth productivity of V93 may have been sustained during the drought by its biomass partitioning pattern of allocating higher proportions of its root biomass to small and fine roots and its aboveground biomass to foliage. These results suggest that a variety such as V93 could be more susceptible to changes in C fixation and water uptake with recurrent drought.
\end{abstract}

\section{Introduction}

Productivity of loblolly pine (Pinus taeda L.) plantations in the southeastern United States has improved with widespread planting of genetically improved seedlings. Up to $25 \%$ tree volume gains have been reached by half-sib, openpollinated loblolly pine families [1]; and it is estimated that tree volume gains of more than $50 \%$ can be achieved by loblolly pine varieties when paired with intensive silviculture to optimize growth [2-4]. However, the greater genetic uniformity of varieties relative to more conventionally- planted half-sib genotypes may lead to greater likelihood of genotype $\times$ environment $(\mathrm{G} \times \mathrm{E})$ interactions in growth and the physiological processes that govern growth patterns [4].

For decades, $\mathrm{G} \times \mathrm{E}$ considerations of productivity and drought hardiness have affected loblolly pine plantation decision-making in the western portion of the loblolly pine range. Numerous genotype studies demonstrated that when planted in common environments in the western portion of the loblolly pine range, genotypes from the eastern portion of its range are taller and faster growing than local genotypes 
[5-9]. Eastern families have also shown tendencies to produce trees with straighter stems [8] and allocate standlevel volume to fewer trees per hectare [10] relative to western families. Stands of eastern families thus often produce larger, more economically valuable trees than those of western families $[6,11]$. Consequently, loblolly pine from eastern genotypes has been commonly planted in the western portion of loblolly pine's range in favor of local genotypes since the 1980s. However, an offsetting factor for volume gains achievable for eastern genotypes planted in the region is drought injury and mortality. Eastern genotypes are adapted to a climate with greater summer rainfall and lower potential evapotranspiration than that of the western portion of the loblolly pine range, so forest managers have generally avoided planting eastern genotypes on soils with poor moisture-holding capacity to lower risks of droughtrelated mortality [12]. As such, genotype selection in the region has been guided by compromises between potential gains in productivity and risk of drought-related mortality. The breadth of knowledge for eastern versus western genotype selection in the western portion of the loblolly pine range was overwhelmingly gained through studies of half-sib genotypes; $\mathrm{G} \times \mathrm{E}$ considerations for varietal genotypes of loblolly pine in the region may be more pronounced and are relatively understudied due to the more recent development of industrial-scale production of varietal loblolly pine. The substantially higher cost of varietal relative to half-sib seedlings (nearly 10 times greater cost per seedling) also contributes to the need to better understand $\mathrm{G} \times \mathrm{E}$ factors that affect productivity.

Leaf-level gas exchange varies among loblolly pine genotypes, and it has been implicated as a potential measure of genotype success [13-15]. Differences in leaf photosynthetic rate, respiration rate, stomatal conductance, and water-use efficiency among genotypes can affect stand-level carbon gain and water use $[16,17]$. Genotype differences in leaf photosynthetic rates are also correlated with growth trends under environmental stresses such as drought; water stress differences have been inferred as a major factor governing $\mathrm{G} \times \mathrm{E}$ interactions in tree growth trends [18]. Leaf-level gas exchange parameters differed among tree genotypes in some studies $[14,19]$, whereas others found no differences $[17,20,21]$. Environmental factors such as air temperature, irradiance, ambient $\mathrm{CO}_{2}$ concentrations, and absolute humidity deficit also affect leaf-level gas exchange [20]. Perhaps because of these variable genetic and environmental effects on leaf-level gas exchange parameters, $\mathrm{G} \times \mathrm{E}$ effects on them have varied in presence [14] and absence [13, 22, 23] in prior studies. Aspinwall et al. [17] suggested that studies of genetic differences in leaf-level gas exchange parameters are more robust by taking repeated measurements over the course of the season to account for seasonal variability in environmental factors and tree size. Gas exchange parameters can also be more strongly related to genotype growth trends by scaling up to the crownlevel using total leaf area estimates $[18,24,25]$.

Although loblolly pine varieties from the eastern portion of the range may be relatively productive in growth and form when grown in the western portion of the loblolly range, the physiological parameters that govern their growth have been relatively understudied in the western portion of the range. Gas exchange parameters of loblolly pine varieties have been predominately studied in the eastern portion of the range, for example, North Carolina [17], Virginia [14], and South Carolina [15]. The Comparing Clonal Lines on Experimental Sites (CCLONES) study of the Forest Biology Research Cooperative is the only previously reported loblolly pine variety trial to the authors' knowledge that includes sites in the western portion of the range (with sites in southwestern Louisiana and Southeastern Texas) [26], but no gas exchange examinations have yet been published from the CCLONES study. The objective of this study was to determine the effects of genotype on seasonal trends in gas exchange parameters at the leaf and crown levels for loblolly pine varieties and half-sib families from the eastern portion of the loblolly pine range grown on a site in the western portion of the range (northwestern Louisiana). During the study, the region experienced an extreme drought in summer as characterized by the U.S. drought monitor scale [27], which offered an opportunity to explore differences in these parameters under droughty conditions of concern for genotype selection practices in the western portion of the loblolly pine range.

\section{Materials and Methods}

2.1. Study Site and Experimental Design. The study site was established in 2004 at the Louisiana State University Agricultural Center Hill Farm Research Station near Homer, LA $(32.749025 \mathrm{~N},-93.04111111 \mathrm{~W})$. Following the removal of the previous 50 -year-old loblolly pine stand, the study site was burned and subsoiled to a $60 \mathrm{~cm}$ depth in September and October 2004, respectively. The study site had two soil series: (1) well-drained Wolfpen soil series (loamy, siliceous, semiactive, thermic Arenic Paleudalfs) loamy fine sand with a deep $(69 \mathrm{~cm})$ argillic layer, and (2) moderately well-drained Sacul soil (fine, mixed, active, thermic Aquic Hapludults) very fine sandy loam with a shallow $(23 \mathrm{~cm})$ argillic layer (USDA SCS 1989). Wolfpen series have moderate extent through the Southern Coastal Plain of Louisiana, Arkansas, and Texas; Sacul series have broad extent through the Western Coastal Plain of Louisiana, Arkansas, and Texas and the Southern Coastal Plain of Alabama and Mississippi $[28,29]$. Average precipitation for the study's region is $133 \mathrm{~cm} \cdot \mathrm{yr}^{-1}$; drought conditions are common due to relatively low late-summer precipitation [30]. Temperature and precipitation patterns within this study were obtained from data collected from the National Oceanic and Atmospheric Administration (NOAA) weather station located nearest $(5.9 \mathrm{~km})$ the study site. Long-term (30-year) averages of temperature and precipitation for the region in which the study site was located (Figure 1) were obtained from the Southern Climate Impacts Planning Program (SCIPP) of NOAA; the study site location was within the North Central Louisiana region within the SCIPP Average Monthly Temperature and Precipitation Tool [31]. In 2010, conditions were somewhat droughty by the date of the first measurements of the year, so volumetric soil moisture was measured concurrently with gas exchange measurements to further 


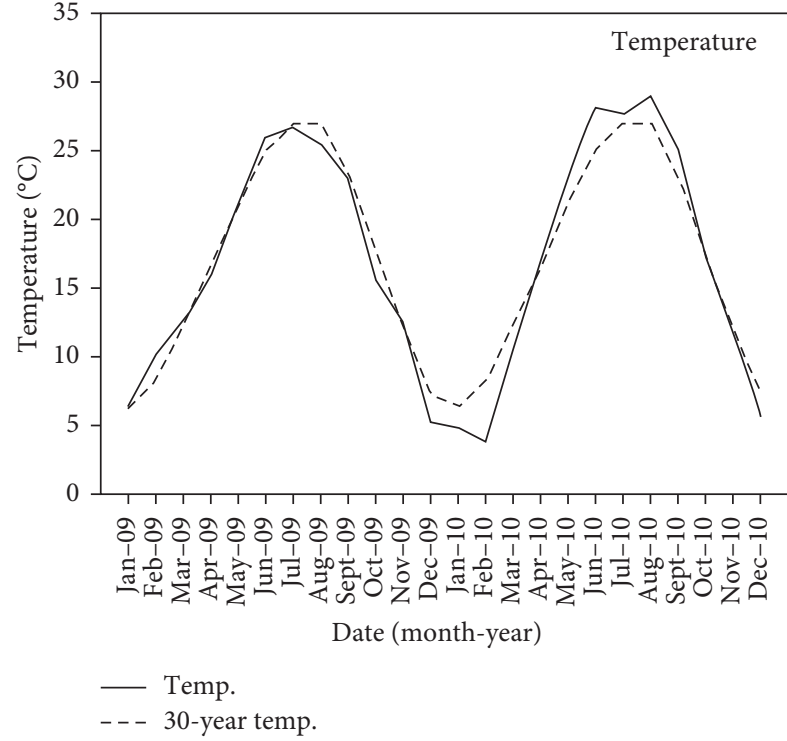

(a)

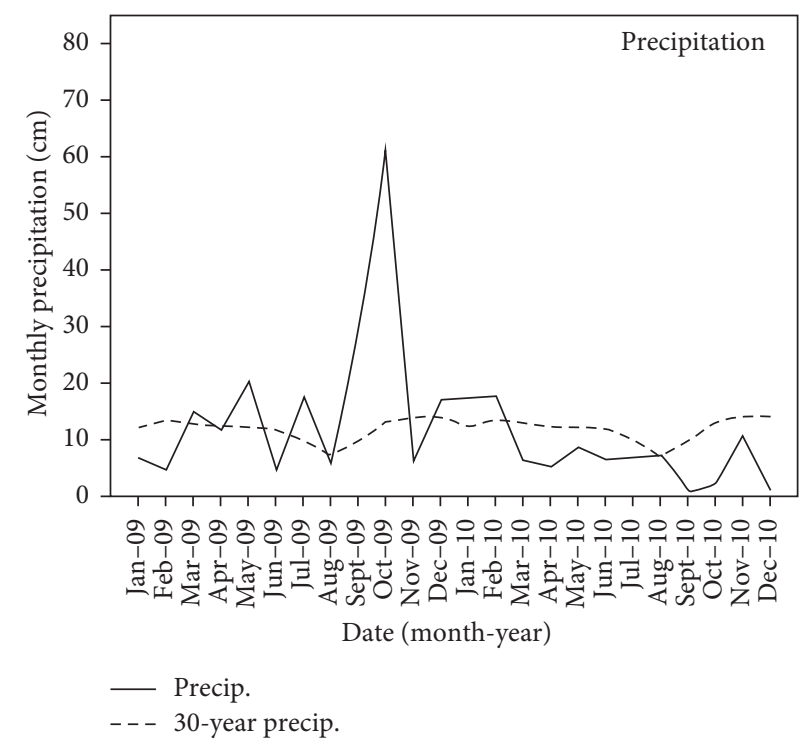

(b)

FIGURE 1: Monthly total precipitation, average monthly temperatures, and 30-year averages of precipitation and temperatures for a study site in North Central Louisiana.

characterize environmental conditions. Soil moisture was measured to a $15-\mathrm{cm}$ depth at a point within $1 \mathrm{~m}$ of trees on which gas exchange measurements were taken using a TDR 200 time-domain reflectometry probe (Spectrum Technologies, Inc., Paxinos, PA, USA).

Containerized seedlings of four genotypes of loblolly pine from the eastern portion of the loblolly pine range were planted by hand in January 2005. Seedlings were planted in 0.1 -ha plots on a $1.8 \mathrm{~m} \times 4.9 \mathrm{~m}$ spacing. Plots were separated by at least $4 \mathrm{~m}$ on all sides to ensure independence of treatments. Genotypes of this study consisted of two half-sib genotypes (HS756 and HS8103) and two varieties (V9 and V93). The HS756 genotype was included in this study because of its ubiquity in operational planting and breeding programs in the southeastern United States; HS756 has a compact crown and fast growth rate. The V93 genotype was propagated from HS756 and shares its compact crown and fast growth rate. The HS8103 and V9 also have fast growth potential but they are characterized by relatively large crowns. Genotypes were replicated 12 times; the genotype treatment was applied as a randomized complete block design. There were three blocks for the experiment, with each genotype replicated four times per block. Soil type and depth to the argillic horizon within the Wolfpen soil type were the blocking factors.

After planting, applications of sulfometuron methyl (Oust XP) were applied in a $1.8 \mathrm{~m}$ band over seedlings in March and September 2005 to enhance establishment success. In April 2006, August 2006, and April 2007 the site was rotary-mowed to eliminate volunteer loblolly pine seedlings. Brush sawing was also conducted within rows each June from 2005 through 2007 to eliminate volunteer loblolly pine seedlings. In July 2005 and July 2007, all hardwood saplings within rows were suppressed with a basal bark application of triclopyr (Garlon 4) herbicide.
2.2. Leaf-Level Gas Exchange. Leaf-level gas exchange parameters of light-saturated photosynthetic rate $\left(A_{\text {sat }}\right)$ and conductance $\left(g_{s}\right)$ were measured using a Li-6400 portable photosynthesis system with a $6-\mathrm{cm}^{2}$ cuvette having a bluered LED light source (LiCor, Inc., Lincoln, NE, USA) in April, June, August, and November 2009 and in May, June, August, and September 2010. Gas exchange parameters were measured on one tree per plot; measurement trees were selected based on representative size, crown form, and absence of deformities (forking and crown damage) and damage from insects and disease. Gas exchange measurements were taken on a branch in the upper-middle portion of the crown on the first fully elongated flushes of previousyear and current-year foliage. Saturating light (photosynthetically active radiation of $2000 \mu \mathrm{mol} \cdot \mathrm{m}^{-2} \cdot \mathrm{s}^{-1}$ ) and constant $\mathrm{CO}_{2} \quad$ concentrations $\left(400 \mu \mathrm{mol} \cdot \mathrm{mol}^{-1}\right)$ were maintained during measurements. Measurements were conducted between 800 and 1700 Eastern Standard Time, and measurements were stopped when ambient temperatures exceeded $27^{\circ} \mathrm{C}$ to avoid reductions in photosynthetic capacity associated with temperature-induced stomatal closure [9]. Intrinsic water-use efficiency (iWUE; $\mu \mathrm{mol} \cdot \mathrm{mmol}^{-1}$ ) was calculated by dividing saturated net photosynthesis $\left(A_{\mathrm{sat}} \cdot \mu \mathrm{mol} \cdot \mathrm{CO}_{2} \cdot \mathrm{m}^{-2} \cdot \mathrm{s}^{-1}\right)$ by stomatal conductance $\left(g_{s} ; \mathrm{mmol} \cdot \mathrm{m}^{-2} \cdot \mathrm{s}^{-1}\right)$ [32]. Following gas exchange measurements, needles were immediately removed from the cuvette and fascicle diameter was measured to the nearest $0.01 \mathrm{~mm}$ using digital calipers (Mitutoyo America Corporation, City of Industry, CA). The leaf area per fascicle was calculated using the following equation [33]:

$$
A=2 R L(N+\pi),
$$

where $A$ is the fascicle area $\left(\mathrm{cm}^{2}\right), R$ is the radius of needles $(\mathrm{cm}), L$ is the length of the fascicle $(\mathrm{cm})$, and $N$ is the number of needles per fascicle. 
2.3. Net $\mathrm{CO}_{2}$ Assimilation-Light Response Curves. In midAugust through mid-September 2009, net $\mathrm{CO}_{2}$ assimilationlight response curves were measured. This period received approximately two times more precipitation than the 30year average, so it represented a best-case scenario for plant metabolism and growth (Figure 1). By graphically comparing net $\mathrm{CO}_{2}$ assimilation within a range of light levels, light-saturated net photosynthesis $\left(A_{\text {sat }}\right)$, light compensation point (LCP), mitochondrial respiration rate $\left(R_{\mathrm{M}}\right)$, and apparent quantum yield $(Q)$ were determined. Measurements were taken with the Li-6400 photosynthesis system at ten light levels: 2000, 1400, 1000, 600, 400, 200, 100, 50, 20, and $0 \mu \mathrm{mol} \cdot \mathrm{m}^{-2} \cdot \mathrm{s}^{-1}$ photosynthetic photon flux densities (PPFDs). Parameters for the net $\mathrm{CO}_{2}$-light response curves were calculated by fitting response curves to a nonrectangular hyperbola via nonlinear least squares regression [34] using the following equation:

$$
A=A_{\text {sat }} \times\left(\left[1-\left(\frac{1-R_{\mathrm{M}}}{A_{\mathrm{sat}}}\right)\right]^{(1-\mathrm{PPFD} / \mathrm{LCP})}\right),
$$

where $A$ is the net $\mathrm{CO}_{2}$ assimilation at a given light level, $A_{\text {sat }}$ is light-saturated net $\mathrm{CO}_{2}$ assimilation, $R_{\mathrm{M}}$ is the mitochondrial respiration taken during the day, PPFD is the photosynthetic photon flux density, and LCP is the light compensation point. Apparent quantum yield (Q) was calculated using the first derivative of the above equation:

$$
\mathrm{Q}=\left(\frac{A_{\mathrm{sat}}}{R_{\mathrm{M}}}\right) \times\left(\frac{1-\mathrm{LCP}}{A_{\mathrm{sat}}}\right) \times \ln \left(\frac{1-\mathrm{LCP}}{A_{\mathrm{sat}}}\right) .
$$

2.4. Crown-Level Biomass and Gas Exchange. Trees were destructively harvested in September of 2009 and 2010 to develop regression equations to estimate crown biomass. For both harvests, six trees (two per block) of each genotype were selected based on the same factors as the measurement trees described above. Prior to felling trees, their total height and diameter at breast height $(1.4 \mathrm{~m}, \mathrm{DBH})$ were measured. After felling, foliage was removed from branches and separated by year of production. Foliage was then oven-dried to constant weight at $40^{\circ} \mathrm{C}$, and dry weights were measured. Equations were developed from these data to estimate crown foliage weight of measurement trees using their height and $\mathrm{DBH}$.

Before foliage samples from the destructive harvests were dried, four subsamples of 50 fascicles each were collected from each foliage flush per tree for specific leaf area (SLA) determination. The leaf per fascicle was calculated using equation (1) (above). All measurements required for the use of equation (1) were collected using the procedures outlined by Bingham [33]. The leaf area values calculated for each fascicle within the 50-fascicle samples were then summed to yield the leaf area for the entire sample. All samples were oven-dried at $40^{\circ} \mathrm{C}$ to constant weight, and the leaf area of each sample was divided by its oven-dry weight to provide the SLA of each 50-fascicle sample. These procedures yielded average SLA values for each genotype.

The SLA values were used as multipliers for the crown foliage weights of all measurement trees estimated by the regression equations. From that multiplication, the crown leaf area of each measurement tree was obtained. All leaflevel parameters $\left(A_{\mathrm{sat}}, g_{s}\right.$, and $\left.i W U E\right)$ were multiplied by the crown leaf area to scale up to the crown level. In 2009, tree height and $\mathrm{DBH}$ were measured as crown model inputs in August concurrently with gas exchange measurements, which allowed for scaling of gas exchange parameters to the crown level for August. In 2010, tree height and DBH were measured concurrent with all gas exchange measurements, which allowed scaling of gas exchange parameters to the crown level for May, June, August, and September.

2.5. Biomass Partitioning. As part of the 2009 destructive harvest, above- and belowground biomass partitioning patterns were measured. Diameters and length were measured on all branches of each harvested tree. From the foliage (total of all flushes), branch, and stem weights of the harvested tree, ratios of foliage weight to branch weight and branch weight to stem weight were derived. After aboveground biomass was harvested, root systems within the $1 \mathrm{~m}^{3}$ volume of soil around the stump were excavated. Root systems were washed and separated into fine $(<2 \mathrm{~mm}$ diameter), small (2-5 mm diameter), large ( $>5 \mathrm{~mm}$ diameter), and taproot. After the root components were separated, they were dried to constant weight at $40^{\circ} \mathrm{C}$, and then dry weights were measured. A relatively negligible amount of root biomass was found below $50 \mathrm{~cm}$ within the soil profile, particularly for fine and small roots; weights of all root types reported are within the upper $50 \mathrm{~cm}$ of soil.

2.6. Tree Growth. In January-February 2006, 2008, 2009, 2010, and 2011, tree height and DBH were measured. In 2006 and 2008 , tree height was measured by a height pole. In the succeeding years, tree height was measured by a hypsometer (Vertex 3, Haglöf Sweden AB, Långsele, Västernorrland, Sverige). Calipers were used to measure DBH. Measurements were taken within the central 0.03 ha of each plot to avoid edge effects on tree growth.

2.7. Data Analysis. Analysis of variance (ANOVA) was conducted at $\alpha=0.05$ for all parameters using the GLIMMIX procedure of the SAS System (SAS Institute, Inc., Cary, NC). When significant main effects were found in ANOVA, an F-protected least significant difference (LSD) means separation was performed by the LINES option of the LSMEANS statement. When ANOVA determined significant interactions, the SLICEBY, TUKEY, and LINES options of the SLICE statement were used to conduct Tukey means separations within the interaction. The COVTEST statement was used to carry out a restricted likelihood test of homogeneity of variance for variables within the ANOVA model. Parameters for which significant heterogeneity of variance were found were log-transformed for ANOVA (Table 1).

For leaf- and crown-level (2010 only), $A_{\text {sat }}, g_{s}$, and $i W U E$, ANOVA were performed separately for each foliage flush and year of observation. The model for these 
TABle 1: Tests of fixed effects of leaf-level and crown-level (Crn) photosynthetic capacity $\left(A_{\text {sat }}\right)$, conductance $\left(g_{s}\right)$, and intrinsic use efficiency $(i W U E)$ in previous-year (PY) and current-year (CY) foliage flushes as well as foliage area (FA) and biomass partitioning parameters (foliage : branch mass, branch : stem mass, foliage mass, branch mass, stem mass, branch diameter, branch length, branch angle, taproot weight, fine: total root mass, and small: total root mass) of four loblolly pine genotypes in North Central Louisiana, USA.

\begin{tabular}{|c|c|c|c|c|c|c|}
\hline \multirow[b]{2}{*}{ Parameter } & \multicolumn{2}{|c|}{ Genotype } & \multicolumn{2}{|c|}{ Date/flush } & \multicolumn{2}{|c|}{$\begin{array}{c}\text { Genotype } \\
\times \text { date/ } \\
\text { flush }\end{array}$} \\
\hline & $\mathrm{df}$ & $P$ & $\mathrm{df}$ & $P$ & df & $P$ \\
\hline PY-A sat 2009 & 3 & 0.439 & 2 & $<0.0001$ & 6 & 0.005 \\
\hline CY-A sat 2009 & 3 & 0.031 & 2 & $<0.0001$ & 6 & 0.012 \\
\hline PY-A sat 2010 & 3 & 0.802 & 3 & $<0.0001$ & 9 & 0.044 \\
\hline CY-A sat 2010 & 3 & 0.553 & 2 & $<0.0001$ & 6 & 0.046 \\
\hline PY -g 2009 & 3 & 0.255 & 2 & $<0.0001$ & 6 & 0.047 \\
\hline CY-g 2009 & 3 & 0.438 & 2 & $<0.0001$ & 6 & 0.098 \\
\hline PY-g 2010 & 3 & 0.897 & 3 & $<0.0001$ & 9 & 0.041 \\
\hline$C Y-g_{s} 2010$ & 3 & 0.2007 & 2 & $<0.0001$ & 6 & 0.010 \\
\hline PY-iWUE 2009 & 3 & 0.994 & 2 & $<0.0001$ & 6 & 0.999 \\
\hline CY-iWUE 2009 & 3 & 0.332 & 2 & $<0.0001$ & 6 & 0.244 \\
\hline PY-iWUE 2010 & 3 & 0.815 & 2 & $<0.0001$ & 6 & 0.598 \\
\hline CY-iWUE 2010 & 3 & 0.337 & 2 & $<0.0001$ & 6 & 0.268 \\
\hline Crn-FA 2009 & 3 & 0.0002 & 1 & $<0.0001$ & 3 & 0.010 \\
\hline Crn-A sat 2009 & 3 & 0.974 & 1 & 0.912 & 3 & 0.001 \\
\hline Crn-gs 2009 & 3 & 0.216 & 1 & 0.0001 & 3 & 0.001 \\
\hline Crn-iWUE 2009 & 3 & 0.086 & 1 & 0.104 & 3 & 0.045 \\
\hline PY-CrnA $A_{\text {sat }} 2010$ & 3 & 0.013 & 3 & $<0.0001$ & 9 & 0.859 \\
\hline CY-CrnA $A_{\text {sat }} 2010$ & 3 & 0.019 & 2 & $<0.0001$ & 6 & 0.806 \\
\hline PY-Crng 2010 & 3 & $<0.0001$ & 3 & $<0.0001$ & 9 & 0.097 \\
\hline CY-Crng 2010 & 3 & $<0.0001$ & 2 & $<0.0001$ & 6 & 0.155 \\
\hline PY-CrniWUE 2010 & 3 & 0.493 & 3 & $<0.0001$ & 9 & 0.986 \\
\hline CY-CrniWUE 2010 & 3 & 0.897 & 2 & $<0.0001$ & 6 & 0.642 \\
\hline Foliage: branch & 3 & 0.020 & & & & \\
\hline Branch: stem & 3 & 0.020 & & & & \\
\hline Foliage mass & 3 & 0.063 & & & & \\
\hline Branch mass & 3 & 0.030 & & & & \\
\hline Stem mass & 3 & 0.187 & & & & \\
\hline Branch dia. & 3 & 0.021 & & & & \\
\hline Branch angle & 3 & 0.012 & & & & \\
\hline Branch length & 3 & 0.151 & & & & \\
\hline Taproot wt. & 3 & 0.045 & & & & \\
\hline Fine: total & 3 & 0.040 & & & & \\
\hline Small: total & 3 & 0.004 & & & & \\
\hline
\end{tabular}

For each parameter, degrees of freedom (df) and probability of a greater $\mathrm{F}$ (P) are provided. Fixed effects for leaf-level parameters are genotype, date, and genotype $\times$ date; for crown-level parameters in 2009 fixed effects are genotype, foliage flush, and genotype $\times$ flush; for biomass partitioning parameters, the fixed effect is genotype.

parameters was a repeated measures model with an autoregressive correlation structure that included genotype, month, and the family $\times$ month interaction as fixed effects and block and its interaction with genotype as random effects. The same model was used for ANOVA of tree height and $\mathrm{DBH}$, with year as an independent variable instead of month. Analyses of variance for light response parameters (LCP, $R_{\mathrm{M}}$, and $\mathrm{Q}$ ), crown-level gas exchange parameters ( $A_{\text {sat }}, R_{\mathrm{M}}, g_{s}$, and $i W U E$ ) of 2009 , and biomass partitioning parameters (biomass component weight ratios, branch dimensions, and root dimensions) were conducted with a model that included genotype as a fixed effect and block and its interaction with genotype as random effects. Analysis of variance for crown-level gas exchange parameters of 2009 was performed for each foliage flush (Table 1).

Procedures for developing the equations used to estimate foliage weight were consistent with those of Blazier et al. [35]. Equation development consisted of two phases, both conducted with the SAS system: (1) stepwise regression with the REG procedure to identify variables that significantly ( $\alpha$ $=0.15$ ) affected foliage biomass and (2) nonlinear regression with the NLIN procedure of foliage weight with variables identified as significant in stepwise regression. Equation procedures were performed for each foliage flush and genotype.

\section{Results}

3.1. Temperature and Precipitation. There was a contrast in temperature and precipitation patterns in the two years of this study (Figure 1). Total annual precipitation of 2009 was 2.5 times greater than the 30 -year average precipitation, with early fall having substantially greater rainfall than the longterm average. Temperatures in 2009 were similar to or lower than the long-term average throughout the year, with late summer and fall being 6\% lower in mean monthly temperatures than the long-term average. Total annual precipitation of 2010 was $36 \%$ lower than the 30 -year average; this annual precipitation was the third-lowest annual precipitation level for North Central Louisiana from 1895 through 2010 [36]. Monthly mean temperatures of 2010 exceeded the 30-year average in spring and summer. Summer temperatures of 2010 were the highest on record for North Central Louisiana from 1895 through 2010 [36]. Soil moisture continually declined throughout 2010, going from $11.2 \%$ in May to $0.38,0.27$, and $0.01 \%$ in June, August, and September, respectively (data not shown).

3.2. Leaf-Level Gas Exchange and Light Response Curve Parameters. The V93 genotype differed from the other genotypes in $A_{\text {sat }}$ and $g_{s}$ on several dates (significant genotype $\times$ date interaction). In April 2009, V93 had lower $A_{\text {sat }}$ than HS756 in previous-year foliage (Table 2). In September 2010, V93 had lower $A_{\text {sat }}$ than HS8103 in current-year foliage. In August 2009, V93 had lower $g_{s}$ than HS756 in current-year foliage (Table 3 ). In the current-year foliage flush in September 2010, $g_{s}$ of V93 was lower than that of all other genotypes (Table 3 ).

The HS8103 genotype had relatively high $A_{\text {sat }}$ in June 2009 and September 2010 (Table 2). In June 2009, HS8103 had greater $A_{\text {sat }}$ than HS756 and V9 in previous- and current-year foliage. In September 2010, HS8103 had greater $A_{\text {sat }}$ than the HS756 and V93 genotypes in the previous-year and current-year foliage flushes, respectively.

For some leaf-level parameters, no differences were found among genotypes (data not shown). No differences in $i W U E$ were found in either year. No differences were found in $R_{\mathrm{M}}$, LCP, and $Q$. 
TABLE 2: Light-saturated photosynthesis $\left(A_{\mathrm{sat}} ; \mu \mathrm{mol} \cdot \mathrm{m}^{-2} \cdot \mathrm{s}^{-1}\right)$ of previous- and current-year foliage of loblolly pine genotypes at a site in North Central Louisiana in 2009 (temperate year) and 2010 (droughty year).

\begin{tabular}{|c|c|c|c|c|c|c|c|c|}
\hline & \multicolumn{4}{|c|}{2009} & \multicolumn{4}{|c|}{2010} \\
\hline & April & June & August & November & May & June & August & September \\
\hline \multicolumn{9}{|c|}{ Previous year } \\
\hline HS756 & $5.132^{\mathrm{a}}$ & $3.725^{\mathrm{b}}$ & $5.918^{\mathrm{a}}$ & - & $4.792^{\mathrm{a}}$ & $1.625^{\mathrm{a}}$ & $0.596^{\mathrm{a}}$ & $0.206^{\mathrm{b}}$ \\
\hline HS8103 & $4.723^{\mathrm{ab}}$ & $4.788^{\mathrm{a}}$ & $5.507^{\mathrm{a}}$ & - & $5.182^{\mathrm{a}}$ & $1.404^{\mathrm{a}}$ & $0.554^{\mathrm{a}}$ & $0.562^{\mathrm{a}}$ \\
\hline V9 & $4.940^{\mathrm{ab}}$ & $3.482^{\mathrm{b}}$ & $5.627^{\mathrm{a}}$ & - & $4.682^{\mathrm{a}}$ & $1.776^{\mathrm{a}}$ & $0.671^{\mathrm{a}}$ & $0.325^{\mathrm{ab}}$ \\
\hline V93 & $3.888^{\mathrm{b}}$ & $4.226^{\mathrm{ab}}$ & $5.965^{\mathrm{a}}$ & - & $4.387^{\mathrm{a}}$ & $1.856^{\mathrm{a}}$ & $0.614^{\mathrm{a}}$ & $0.252^{\mathrm{ab}}$ \\
\hline \multicolumn{9}{|c|}{ Current year } \\
\hline HS756 & - & $4.567^{\mathrm{b}}$ & $6.503^{\mathrm{a}}$ & $5.436^{\mathrm{a}}$ & - & $3.127^{\mathrm{a}}$ & $1.744^{\mathrm{a}}$ & $0.371^{\mathrm{ab}}$ \\
\hline HS8103 & - & $5.620^{\mathrm{a}}$ & $6.059^{\mathrm{a}}$ & $5.697^{\mathrm{a}}$ & - & $3.001^{\mathrm{a}}$ & $1.650^{\mathrm{a}}$ & $0.625^{\mathrm{a}}$ \\
\hline V9 & - & $4.471^{\mathrm{b}}$ & $6.205^{\mathrm{a}}$ & $5.158^{\mathrm{a}}$ & - & $3.228^{\mathrm{a}}$ & $1.567^{\mathrm{a}}$ & $0.382^{\mathrm{ab}}$ \\
\hline V93 & - & $5.454^{\mathrm{ab}}$ & $6.203^{\mathrm{a}}$ & $5.415^{\mathrm{a}}$ & - & $3.401^{\mathrm{a}}$ & $1.549^{\mathrm{a}}$ & $0.227^{\mathrm{b}}$ \\
\hline
\end{tabular}

For each foliage flush, means within a column followed by different letters are different at $P<0.05$.

TABLE 3: Stomatal conductance $\left(g_{s} ; \mathrm{mmol} \cdot \mathrm{m}^{-2} \cdot \mathrm{s}^{-1}\right)$ of previous- and current-year foliage of loblolly pine genotypes at a site in North Central Louisiana in 2009 (temperate year) and 2010 (droughty year).

\begin{tabular}{|c|c|c|c|c|c|c|c|c|}
\hline & \multicolumn{4}{|c|}{2009} & \multicolumn{4}{|c|}{2010} \\
\hline & April & June & August & November & May & June & August & September \\
\hline \multicolumn{9}{|c|}{ Previous year } \\
\hline HS756 & $0.054^{\mathrm{a}}$ & $0.070^{\mathrm{a}}$ & $0.073^{\mathrm{a}}$ & - & $0.063^{\mathrm{a}}$ & $0.015^{\mathrm{a}}$ & $0.006^{\mathrm{a}}$ & $0.003^{\mathrm{a}}$ \\
\hline HS8103 & $0.040^{\mathrm{ab}}$ & $0.082^{\mathrm{a}}$ & $0.063^{\mathrm{a}}$ & - & $0.072^{\mathrm{a}}$ & $0.011^{\mathrm{a}}$ & $0.005^{\mathrm{a}}$ & $0.004^{\mathrm{a}}$ \\
\hline V9 & $0.043^{\mathrm{ab}}$ & $0.062^{\mathrm{a}}$ & $0.057^{\mathrm{a}}$ & - & $0.058^{\mathrm{a}}$ & $0.014^{\mathrm{a}}$ & $0.006^{\mathrm{a}}$ & $0.004^{\mathrm{a}}$ \\
\hline V93 & $0.032^{\mathrm{b}}$ & $0.067^{\mathrm{a}}$ & $0.078^{\mathrm{a}}$ & - & $0.062^{\mathrm{a}}$ & $0.016^{\mathrm{a}}$ & $0.006^{\mathrm{a}}$ & $0.002^{\mathrm{a}}$ \\
\hline \multicolumn{9}{|c|}{ Current year } \\
\hline HS756 & - & $0.083^{\mathrm{a}}$ & $0.082^{\mathrm{a}}$ & $0.043^{\mathrm{a}}$ & - & $0.033^{\mathrm{a}}$ & $0.013^{\mathrm{a}}$ & $0.003^{\mathrm{a}}$ \\
\hline HS8103 & - & $0.096^{\mathrm{a}}$ & $0.070^{\mathrm{ab}}$ & $0.050^{\mathrm{a}}$ & - & $0.030^{\mathrm{a}}$ & $0.012^{\mathrm{a}}$ & $0.005^{\mathrm{a}}$ \\
\hline V9 & - & $0.076^{\mathrm{a}}$ & $0.062^{\mathrm{ab}}$ & $0.044^{\mathrm{a}}$ & - & $0.032^{\mathrm{a}}$ & $0.013^{\mathrm{a}}$ & $0.005^{\mathrm{a}}$ \\
\hline V93 & - & $0.094^{\mathrm{a}}$ & $0.058^{\mathrm{b}}$ & $0.052^{\mathrm{a}}$ & - & $0.033^{\mathrm{a}}$ & $0.011^{\mathrm{a}}$ & $0.002^{\mathrm{b}}$ \\
\hline
\end{tabular}

For each year and foliage flush, means within a column followed by different letters are different at $P<0.05$.

3.3. Crown Area and Gas Exchange. Genotype differences (significant genotype main effect) in the crown foliage area (Crn-FA) and crown-level $A_{\text {sat }}$, and $g_{s}$ (Crn- $A_{\text {sat }}$, Crn- $g_{s}$, respectively) were found in both years of the study (Table 4 ). In 2009, V93 and HS756 had greater Crn-FA than the other two genotypes in both foliage flushes. In 2010, Crn-FA of HS756 and V9 had greater Crn-FA than the other two genotypes in both foliage flushes. The V93 genotype had greater Crn- $g_{s}$ than the HS8103 and V9 genotypes in both foliage flushes in 2009. In current-year foliage in 2009, Crn$g_{s}$ of HS756 exceeded that of all other genotypes. In 2010, Crn- $g_{s}$ of HS756 was greater than that of the HS8103 and V93 genotypes in both foliage flushes. The V93 genotype also had lower Crn- $g_{s}$ than V9 in previous-year foliage.

The HS756 genotype had relatively high Crn- $A_{\text {sat }}$ in both years of the study (Table 4). In 2009, HS756 had greater Crn$A_{\text {sat }}$ than HS8103 and V9 in previous- and current-year foliage. In 2010, HS756 and V9 had higher Crn- $A_{\text {sat }}$ than V93 in both foliage flushes.

Crown-level $i W U E$ (Crn-iWUE) differed in current-year foliage in August 2009, but there were no differences among genotypes in Crn-iWUE in 2010. In August 2009, Crn-iWUE of V93 was greater than that of HS756 in current-year foliage (Figure 2). Crn-iWUE means observed in 2010 (averaged for all measurement dates) were 96.2, 95.8, 98.6, and $88.2 \mu \mathrm{mol} \cdot \mathrm{mmol}^{-1}$ for HS756, HS8103, V9, and V93, respectively, in previous-year foliage. Current-year Crn-iWUE in 2010 averaged for all measurement dates were 97.6, 100.4, 101.0, and $103.8 \mu \mathrm{mol} \cdot \mathrm{mmol}^{-1}$ for HS756, HS8103, V9, and V93, respectively (data not shown).

3.4. Tree Growth and Biomass Partitioning. There was a significant genotype $\times$ date interaction for tree height (Figure 3); the HS8103 genotype had relatively low height in all observed years after 2006. In 2008, HS756 and V93 had greater height than HS8103. In 2009 through 2011, HS8103 had lower height than all other genotypes. There was no difference among genotypes in $\mathrm{DBH}$ in any year (data not shown).

The genotypes differed in their aboveground biomass partitioning, with the greatest contrasts occurring between HS756 and V93 (Table 5). The V93 genotype had lower branch diameter, higher foliage: branch weight, and lower branch : stem weight than HS756. Taproot weight of HS756 exceeded that of the V9 and V93 genotypes. There were no differences among the genotypes in average branch length (data not shown). Foliage mass, which did not differ among 
TABLE 4: Crown foliage area $\left(\mathrm{m}^{2}\right)$, light-saturated photosynthesis $\left(\mu \mathrm{mol} \cdot \mathrm{m}^{-2}\right)$, conductance $\left(\mathrm{mmol} \cdot \mathrm{s}^{-1}\right)$, and transpiration $\left(\mathrm{mmol} \cdot \mathrm{s}^{-1}\right)$ of previous-year and current-year foliage of loblolly pine genotypes at a site in North Central Louisiana in August 2009 and in 2010 (averaged for May, June, August, and September).

\begin{tabular}{|c|c|c|c|c|c|c|c|c|}
\hline & \multicolumn{4}{|c|}{ Previous-year foliage } & \multicolumn{4}{|c|}{ Current-year foliage } \\
\hline & HS756 & HS8103 & V9 & V93 & HS756 & HS8103 & V9 & V93 \\
\hline \multicolumn{9}{|l|}{ Foliage area } \\
\hline August 2009 & $13.81^{\mathrm{a}}$ & $3.11^{\mathrm{b}}$ & $4.50^{\mathrm{b}}$ & $13.37^{\mathrm{a}}$ & $28.82^{\mathrm{a}}$ & $9.72^{\mathrm{b}}$ & $9.79^{\mathrm{b}}$ & $23.24^{\mathrm{a}}$ \\
\hline May-September average 2010 & $77.57^{\mathrm{a}}$ & $38.52^{\mathrm{b}}$ & $57.44^{\mathrm{a}}$ & $26.28^{\mathrm{c}}$ & $169.85^{\mathrm{a}}$ & $41.66^{\mathrm{b}}$ & $139.30^{\mathrm{a}}$ & $30.43^{\mathrm{b}}$ \\
\hline Photosynthesis & & & & & & & & \\
\hline August 2009 & $81.41^{\mathrm{a}}$ & $18.00^{\mathrm{b}}$ & $23.35^{\mathrm{b}}$ & $80.46^{\mathrm{a}}$ & $183.10^{\mathrm{a}}$ & $57.70^{\mathrm{b}}$ & $59.10^{\mathrm{b}}$ & $145.54^{\mathrm{a}}$ \\
\hline May-September average 2010 & $59.43^{\mathrm{a}}$ & $17.35^{\mathrm{ab}}$ & $51.71^{\mathrm{a}}$ & $8.81^{\mathrm{b}}$ & $100.66^{\mathrm{a}}$ & $30.44^{\mathrm{ab}}$ & $116.10^{\mathrm{a}}$ & $11.80^{\mathrm{b}}$ \\
\hline \multicolumn{9}{|l|}{ Conductance } \\
\hline August 2009 & $1.09^{\mathrm{a}}$ & $0.20^{\mathrm{b}}$ & $0.26^{\mathrm{b}}$ & $1.11^{\mathrm{a}}$ & $2.55^{\mathrm{a}}$ & $0.67^{\mathrm{c}}$ & $0.67^{\mathrm{c}}$ & $1.41^{\mathrm{b}}$ \\
\hline May-September average 2010 & $0.88^{\mathrm{a}}$ & $0.44^{\mathrm{bc}}$ & $0.71^{\mathrm{ab}}$ & $0.29^{c}$ & $1.93^{\mathrm{a}}$ & $0.42^{\mathrm{b}}$ & $1.67^{\mathrm{a}}$ & $0.27^{\mathrm{b}}$ \\
\hline
\end{tabular}

For each parameter, date, and foliage flush, means within a row followed by different letters are different at $P<0.05$.

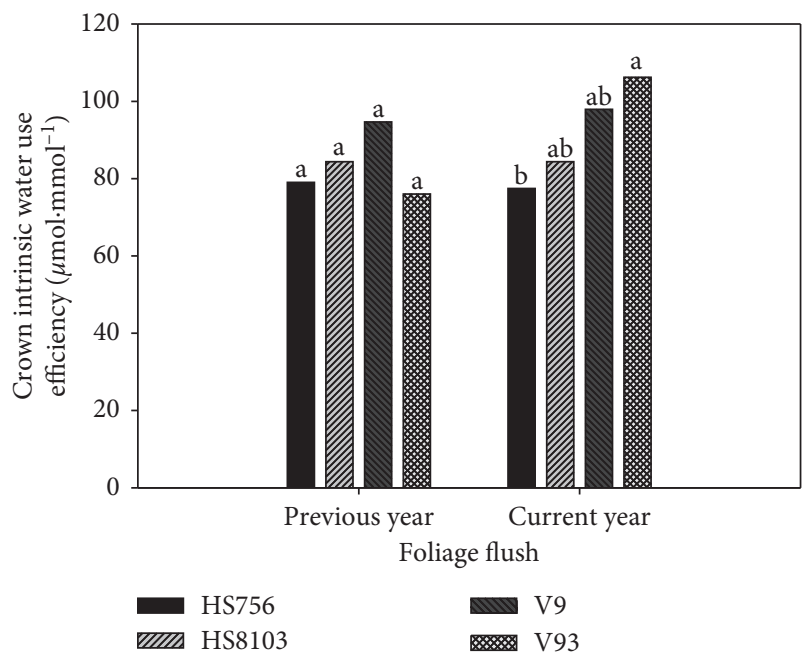

Figure 2: Crown intrinsic water use efficiency of previous- and current-year foliage flushes of loblolly pine genotypes from the eastern portion of the species' range grown at a site in North Central Louisiana in 2009.

genotypes, was 7.8, 5.1, 4.8, and $3.3 \mathrm{~kg}$ for HS756, HS8103, V9, and V93, respectively. V93 had lower branch mass $(2.0 \mathrm{~kg})$ than that of HS756 $(6.9 \mathrm{~kg}) ; \mathrm{HS} 8103$ and V9 had stem mass of 4.7 and $3.6 \mathrm{~kg}$, respectively. There were no differences in stem mass among genotypes; HS756, HS8103, V9, and V93, respectively, had stem mass of $8.5,7.6,5.8$, and $6.2 \mathrm{~kg}$, respectively.

No differences were observed among genotypes in most of the types of roots in the upper $50 \mathrm{~cm}$ of soil, but they differed in root biomass partitioning patterns. Fine, small, large, and total root biomass were similar for the genotypes. Taproot biomass of HS756 (2000 g) was greater than that of V9 $(1000 \mathrm{~g})$ and V93 $(1000 \mathrm{~g})$ (data not shown). The HS756 genotype had lower fine : total and small : total root weight than V93; small : total root weight of HS756 was also lower than that of HS8103 (Table 5).

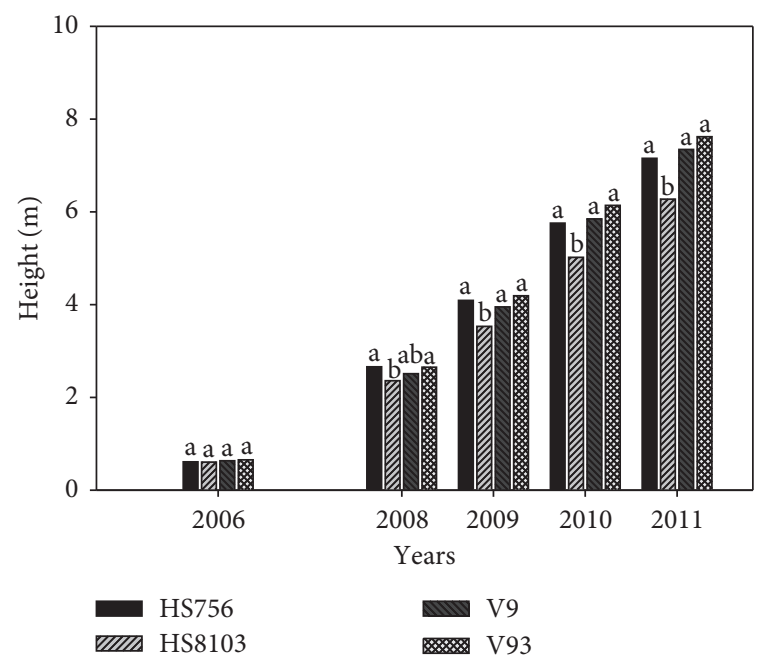

FIGURE 3: Tree height of loblolly pine genotypes from the eastern portion of the species' range grown at a site in North Central Louisiana.

\section{Discussion}

At this Western Gulf site and under contrasting precipitation patterns, the eastern genotypes had short-term differences in leaf-level gas exchange parameters. Crownlevel gas exchange and light response parameters also differed among the genotypes, and the pattern in genotype differences in crown gas exchange parameters varied in the two years observed. These genotype differences in leaf- and crown-level gas exchange parameters did not completely align with genotype variations in growth, suggesting factors other than these parameters also influenced growth patterns.

The leaf-level gas exchange parameters measured in this study in 2009 were within the ranges found in similar studies of loblolly pine, but values in 2010 were lower than in previous studies. In studies of genotypes of loblolly pine at juvenile ages conducted in the eastern portion of the loblolly 
TABle 5: Above- and belowground biomass partitioning patterns of loblolly pine genotypes at a site in North Central Louisiana in 2009.

\begin{tabular}{lccccccc}
\hline Genotype & $\begin{array}{c}\text { Foliage: branch } \\
\text { mass }\end{array}$ & $\begin{array}{c}\text { Branch: stem } \\
\text { mass }\end{array}$ & $\begin{array}{c}\text { Branch } \\
\text { diameter }(\mathrm{cm})\end{array}$ & $\begin{array}{c}\text { Branch } \\
\text { angle }\left(^{\circ}\right)\end{array}$ & Taproot weight $(\mathrm{g})$ & Fine: total root mass & Small: total root mass \\
\hline HS756 & $1.18^{\mathrm{b}}$ & $0.78^{\mathrm{a}}$ & $1.42^{\mathrm{a}}$ & $42.7^{\mathrm{ab}}$ & $2400^{\mathrm{a}}$ & $6.41^{\mathrm{b}}$ & $0.92^{\mathrm{b}}$ \\
HS8103 & $1.23^{\mathrm{ab}}$ & $0.55^{\mathrm{ab}}$ & $1.24^{\mathrm{ab}}$ & $39.7^{\mathrm{b}}$ & $2100^{\mathrm{ab}}$ & $7.19^{\mathrm{ab}}$ & $1.87^{\mathrm{a}}$ \\
V9 & $1.56^{\mathrm{ab}}$ & $0.59^{\mathrm{ab}}$ & $1.22^{\mathrm{ab}}$ & $48.1^{\mathrm{ab}}$ & $1500^{\mathrm{b}}$ & $8.87^{\mathrm{ab}}$ & $1.23^{\mathrm{ab}}$ \\
V93 & $1.66^{\mathrm{a}}$ & $0.33^{\mathrm{b}}$ & $1.02^{\mathrm{b}}$ & $51.1^{\mathrm{a}}$ & $1700^{\mathrm{b}}$ & $12.14^{\mathrm{a}}$ & $1.78^{\mathrm{a}}$ \\
\hline
\end{tabular}

For each parameter, means within a column followed by different letters are different at $P<0.05$.

pine range, $A_{\text {sat }}$ ranges of 1.5 to $8.0 \mu \mathrm{mol} \cdot \mathrm{m}^{-2} \cdot \mathrm{s}^{-1}$ and $g_{s}$ values of 0.03 to $0.15 \mathrm{mmol} \cdot \mathrm{m}^{-2} \cdot \mathrm{s}^{-1}$ were reported $[14,17,20]$. The $A_{\text {sat }}$ and $g_{s}$ values of this study in September 2010, which was a period of extreme drought, were substantially below those of the prior studies. These findings suggest that the drought of 2010 reduced the water uptake and photosynthetic capacity at this site. The $A_{\max }$ and $g_{s}$ processes of the V93 genotype appeared more sensitive to droughty conditions than the other genotypes; its $A_{\max }$ was relatively low among genotypes in September 2010, and its $g_{s}$ was lower than all other genotypes in September 2010.

Our findings of genotype differences in leaf-level gas exchange parameters contrast with prior studies of loblolly pine genotypes that found no differences in these parameters $[17,20]$. Aspinwall et al. [17] found no differences in $A_{\text {sat }}$ and $g_{s}$ among loblolly pine genotypes in North Carolina; the authors inferred that their study had lower propensity to find such differences because all genotypes tested were native to the region of the study. However, Yang et al. [20] tested loblolly pine genotypes from disparate regions (Atlantic Coastal Plain and Texas) in North Carolina, conducted their experiment during one year that had greater precipitation than the regional average and one with lower-than-average precipitation, and found no differences in $A_{\text {sat }}, g_{s}$, and $i W U E$. Our results relative to those of Yang et al. [20] could indicate that moving eastern genotypes to the western portion of the loblolly pine range have more potential to differentiate genotype leaf-level gas exchange parameters than moving genotypes to the eastern portion of the range. Further study with a greater array of sites and genotypes is necessary to more comprehensively understand this issue.

Crown foliage area had a dominant influence on crownlevel gas exchange parameters, but the droughty conditions of 2010 also affected genotype differences in crown gas exchange parameters. Genotype differences in Crn- $A_{\text {sat }}$ were identical to those of Crn-FA in 2009, and genotype differences in Crn$g_{s}$ were highly similar to those of Crn-FA in the same year. The two half-sib genotypes of this study were consistent in their differences in Crn-FA and Crn- $g_{s}$ in both years and for both foliage flushes HS756 exceeded HS8103 in each of these parameters, with the exception of Crn- $A_{\text {sat }}$ in current-year foliage, in 2010. Foliage area (and correspondingly Crn- $g_{s}$ ) of the varieties followed different trajectories between 2009 and 2010. In 2009, V93 equaled HS756 in having the highest CrnFA and Crn- $g_{s}$, but in 2010, these parameters for V93 ranked among the lowest of the genotypes. Opposite trends occurred for V9. These results are similar to those of Yáñez et al. [37], in which varieties of loblolly pine had differences in crown characteristics (width and height to live crown in their study) over different site and silvicultural conditions. Yáñez et al. [37] inferred that the crown development of varieties is plastic, which facilitates their responding differently to varied environmental and silvicultural conditions. Our study provided evidence that there was plasticity within the genotypes tested in crown development, occurring in response to drought.

The leaf- and crown-level gas exchange trends did not align with growth trends for all genotypes. The HS8103 genotype consistently had the lowest height growth among genotypes at this site, but none of its leaf-level gas exchange parameters were lower than those of any other genotype. The V93 genotype has been consistently one of the fastestgrowing in terms of height at this site, with its height relative to other genotypes unaffected by the 2010 drought. However, V93 had lower leaf-level $A_{\text {sat }}$ and $g_{s}$ in some of the months observed, particularly during the droughty month of September 2010. Relationships between leaf-level gas exchange and genotype productivity have been inconsistent in prior studies $[3,20]$. Some studies found relationships between gas exchange parameters and growth trends by scaling with estimates of total leaf area as done in this study [24, 25]. In this study, the persistently lower Crn- $g_{s}$ of HS8103 were consistent with its relatively low height growth. Those trends were driven by its relatively low crown foliage area, and crown leaf area has been strongly linked with tree growth [23, 38]. Yang et al. [20] found that leaf area was most strongly related to growth of the fastest and slowest loblolly pine genotypes of their study, but in this study crown foliage area patterns were inconsistent with growth differences between our slowest genotype (HS8103) and all other genotypes that were significantly faster growing in height. Crown foliage area of HS8103 was consistently among the lowest of the genotypes, but it was similar to V9, comparable to V93, and greater than V93 in some flushes and observation dates. Crown foliage area and gas exchange parameters of V93 were often inconsistent with its height growth. Despite having height growth among the highest of the genotypes, it had relatively low Crn-FA, Crn- $A_{\text {sat }}$, and Crn$g_{s}$ in 2010. These results indicate that although V93 showed signs of stress in C fixation and water uptake at this site, other factors facilitated its relatively high productivity in height growth at this site.

The growth and gas exchange trends of V93 and HS756 were illustrative of the variability in these characteristics possible within related genotypes. Their height growth was similar throughout the study, but they had dissimilar gas exchange patterns. King et al. [14] likewise found that 
loblolly pine varieties with shared parents vary in their gas exchange and growth responses to forest management practices and site fertility; they suggested investigating biomass allocation patterns (not measured in their study) to better understand these differences. Crn-FA, Crn- $A_{\text {sat }}$, and Crn- $g_{s}$ of V93 appeared more sensitive to drought than that of HS756, but it may have maintained its height growth through its biomass allocation patterns. The V93 genotype allocated a significantly lower proportion of biomass to branch biomass (via smaller branches) and a higher proportion to foliage biomass than HS756. The V93 genotype allocated higher proportions of belowground biomass to fine and small roots than HS756, which could foster better nutrient acquisition. This relatively efficient foliage biomass allocation and greater allocation of biomass to fine and small roots may have contributed to the higher Crn-iWUE of V93 relative to HS756 in the temperate year of 2009. However, the larger taproot of HS756 could be important for sustaining water uptake during droughty periods as in 2010.

\section{Conclusions}

Growth of these genotypes from the eastern portion of the loblolly pine range at this site in the western part of the range has differentiated, and crown-level gas exchange and biomass allocation patterns have governed the genotype growth differences. The most substantial trends in gas exchange parameters were associated with the V93 genotype's response to drought. In the droughty year, V93 had lower foliage area, $A_{\text {sat }}$ and $g_{s}$ relative to the other faster growing genotypes (HS756 and V9). The lower values of these parameters are particularly of merit relative to HS756, from which V93 was propagated. While the height growth of V93 did not change relative to other genotypes after the drought, its apparent increased sensitivity to drought highlights the potential increased risk associated with establishing loblolly pine plantations of genetically homogenous genotypes of eastern origin in the western portion of the species' range. Drought risk of planting such a genotype could increase if the region experiences more recurrent drought. However, the relatively high growth of V93 and its efficient aboveground biomass allocation of less branch biomass to stem (thereby increasing its value for forest products such as sawtimber) demonstrates the growth and value potential of such a genotype. Further studies of this nature with a greater array of genotypes over more diverse edaphic and climatic conditions will continue to refine knowledge about matching genotypes to sites in a manner that minimize drought risks.

\section{Data Availability}

Data for this project are maintained by Michael Blazier; requests for data can be made to mblazier@agcenter.lsu.edu.

\section{Conflicts of Interest}

The authors declare that they have no conflicts of interest associated with the publication of this article.

\section{Acknowledgments}

This research was funded by the LSU Ag Center and McIntire-Stennis. The authors thank Dylan Dillaway, Kenny Kidd, Brian Finch, Jessica LaGrone, Damien Reynolds, Michael Guilbeaux, Abby Sant, Dani Kennedy, and Chelsea Stringfield for their help with field measurements and the destructive harvest.

\section{References}

[1] R. W. Whetten and R. Kellison, "Research gap analysis for application of biotechnology to sustaining U.S. forests," Journal of Forestry, vol. 108, pp. 193-201, 2010.

[2] H. L. Allen, T. R. Fox, and R. G. Campbell, "What is ahead for intensive pine plantation silviculture in the south?," Southern Journal of Applied Forestry, vol. 29, pp. 62-69, 2005.

[3] T. A. Martin, P. M. Dougherty, and S. E. McKeand, "Strategies and case studies for incorporating ecophysiology into southern pine tree improvement programs," Southern Journal of Applied Forestry, vol. 29, no. 2, pp. 70-79, 2005.

[4] S. E. McKeand, E. J. Jokela, D. A. Huber et al., "Performance of improved genotypes of loblolly pine across different soils, climates, and silvicultural inputs," Forest Ecology and Management, vol. 227, no. 1-2, pp. 178-184, 2006.

[5] O. O. Wells and P. C. Wakeley, "Genotypic variation in survival, growth, and fusiform-rust infection of planted loblolly pine," Forest Science Monographs, vol. 11, p. 40, 1966.

[6] O. O. Wells and C. C. Lambeth, "Loblolly pine provenance test in southern Arkansas- $25^{\text {th }}$ year results," Southern Journal of Applied Forestry, vol. 7, pp. 71-75, 1983.

[7] C. A. Harrington, "Retrospective shoot growth analysis for three seed sources of loblolly pine," Canadian Journal of Forest Research, vol. 21, no. 3, pp. 306-317, 1991.

[8] S. D. Douglass, C. G. Williams, C. C. Lambeth, D. A. Huber, and L. C. Burris, "Family $\times$ environment interaction for sweep in local and nonlocal seed sources of loblolly pine," in Proceedings of the 22nd Southern Forest Tree Improvement Conference, pp. 318-326, Atlanta, GA, USA, June 1993.

[9] M. A. Blazier, T. C. Hennessey, T. B. Lynch, R. F. Wittwer, and M. E. Payton, "Productivity, crown architechture, and gas exchange of North Carolina and Oklahoma/Arkansas loblolly pine families growing on a droughty site in southeastern Oklahoma," Forest Ecology and Management, vol. 194, no. 1-3, pp. 83-94, 2004.

[10] C. B. Talbert and M. R. Strub, "Dynamics of stand growth and yield over 29 years in a loblolly pine source trial in Arkansas," in Proceedings of the 19th Southern Forest Tree Improvement Conference, pp. 30-38, College Station, TX, USA, June 1987.

[11] C. G. Tauer and J. A. Loo-Dinkins, "Seed source variation in specific gravity of loblolly pine grown in a common environment in Arkansas," Forest Science, vol. 36, pp. 1133-1145, 1990.

[12] C. C. Lambeth, P. M. Dougherty, W. T. Gladstone, R. B. McCullough, and O. O. Wells, "Large-scale planting of North Carolina loblolly pine in Arkansas and Oklahoma: a case of gain versus risk," Journal of Forestry, vol. 82, pp. 736-741, 1984.

[13] L. J. Samuelson, "Effects of nitrogen on leaf physiology and growth of different families of loblolly and slash pine," New Forests, vol. 19, no. 1, pp. 95-107, 2000.

[14] N. T. King, J. R. Seiler, T. R. Fox, and K. H. Johnsen, "Postfertilization loblolly pine clone physiology and growth performance," Tree Physiology, vol. 28, no. 5, pp. 703-711, 2008. 
[15] M. C. Tyree, J. R. Seiler, C. A. Maier, and K. H. Johnsen, "Pinus taeda clones and soil nutrient availability: effects of soil organic matter incorporation and fertilization on biomass partitioning and leaf physiology," Tree Physiology, vol. 29, no. 9, pp. 1117-1131, 2009.

[16] R. O. Tesky, B. C. Bongarten, B. M. Cregg, P. M. Dougherty, and T. C. Hennessey, "Physiology and genetics of tree growth response to moisture and temperature stress: an examination of the characteristics of loblolly pine (Pinus taeda L.)," Tree Physiology, vol. 3, pp. 41-61, 1987.

[17] M. J. Aspinwall, J. S. King, S. E. McKeand, and J. Domec, "Leaf-level gas-exchange uniformity and photosynthetic capacity among loblolly pine (Pinus taeda L.) genotypes of contrasting inherent genetic variation," Tree Physiology, vol. 31, no. 1, pp. 78-91, 2011.

[18] J. E. Major and K. H. Johnsen, "Family variation in photosynthesis of 22-year-old black spruce: a test of two models of physiological response to water stress," Canadian Journal of Forest Research, vol. 26, no. 11, pp. 1922-1933, 1996.

[19] D. J. Weston and W. L. Bauerle, "Inhibition and acclimation of C3 photosynthesis to moderate heat: a perspective from thermally contrasting genotypes of Acer rubrum (red maple)," Tree Physiology, vol. 27, no. 8, pp. 1083-1092, 2007.

[20] W. Q. Yang, R. Murthy, P. King, and M. A. Topa, "Diurnal changes in gas exchange and carbon partitioning in needles of fast- and slow-growing families of loblolly pine (Pinus taeda)," Tree Physiology, vol. 22, no. 7, pp. 489-498, 2002.

[21] J. R. Seiler and J. D. Johnson, "Physiological and morphological responses of three half-sib families of loblolly pine to water-stress conditioning," Forest Science, vol. 34, pp. 487495, 1988.

[22] H. E. Bown, M. S. Watt, P. W. Clinton, E. G. Mason, and B. Richardson, "Partitioning concurrent influences of nitrogen and phosphorus supply on photosynthetic model parameters of Pinus radiata," Tree Physiology, vol. 27, no. 3, pp. 335-344, 2007.

[23] D. J. Chmura and M. G. Tjoelker, "Leaf traits in relation to crown development, light interception, and growth of elite families of loblolly pine and slash pine," Tree Physiology, vol. 28 , no. 5, pp. 729-742, 2008.

[24] D. A. Michael, D. I. Dickmann, J. G. Isebrands, and N. D. Nelson, "Photosynthesis patterns during the establishment year within two Populus clones with contrasting morphology and phenology," Tree Physiology, vol. 6, no. 1, pp. 11-27, 1990.

[25] T. Wang, P. M. A. Tigerstedt, and A. Vihera-Aarnio, "Photosynthesis and canopy characteristics in genetically defined families of silver birch (Betula pendula)," Tree Physiology, vol. 15 , no. 10 , pp. $665-671,1995$.

[26] B. Baltunis, D. Huber, and T. Wite, Genetic Analysis of Early Field Growth of Loblolly Pine Clones and Seedlings from the Same Full-Sib Families, University of Florida, Gainsville, FL, USA, 2006.

[27] Forwarn, "U.S. Forest change assessment viewer. Drought assesments maps," 2017, https:/forwarn.forestthreats.org/ fcav $2 /$.

[28] National Cooperative Soil Survey, "Wolfpen series. National cooperative soil survey characterization database," 2003, https://soilseries.sc.egov.usda.gov/OSD_Docs/W/WOLFPEN. html.

[29] National Cooperative Soil Survey, "Sacul series. National cooperative soil survey characterization database," 2015, https://soilseries.sc.egov.usda.gov/OSD_Docs/S/SACUL. html.
[30] United States Department of Agriculture, Soil Conservation Service, Soil Survey of Claiborne Parish, Louisiana, United States Department of Agriculture, Washington, DC, USA, 1989.

[31] Southern Climate Impacts Planning Program (SCIPP), "Average monthly temperature and precipitation tool," June 2018, http://charts.srcc.lsu.edu/.

[32] B. M. Cregg, J. M. Olivas-Garcia, and T. C. Hennessey, "Provenance variation in carbon isotope discrimination of mature ponderosa pine trees at two locations in the Great Plains," Canadian Journal of Forest Research, vol. 30, no. 3, pp. 428-439, 2000.

[33] G. E. Bingham, "Leaf area measurement of pine needles," in LI-1600 Steady State Porometer Instruction Manual, Li-Cor, Inc. Publication No. 8107 01R2, Lincoln, Nebraska, 1983.

[34] P. J. Hanson, R. E. McRoberts, J. G. Isebrands, and R. K. Dixon, "An optimal sampling strategy for determining $\mathrm{CO}_{2}$ exchange-rate as a function of photosynthetic photon flux-density," Photosynthetica, vol. 21, pp. 98-101, 1987.

[35] M. A. Blazier, T. C. Hennessey, T. B. Lynch, and R. F. Wittwer, "Comparison of branch biomass relationships for North Carolina and Oklahoma/Arkansas loblolly pine seed sources growing in southeastern Oklahoma," Forest Ecology and Management, vol. 159, no. 3, pp. 241-248, 2002.

[36] Southern Climate Impacts Planning Program (SCIPP), "Historical climate trends tool," June 2018, http://charts.srcc. lsu.edu/trends/.

[37] M. A. Yáñez, T. R. Fox, and J. R. Seiler, "Early growth responses of loblolly pine varieties and families to silvicultural intensity," Forest Ecology and Management, vol. 356, pp. 204-215, 2015.

[38] R. L. McCrady and E. J. Jokela, "Canopy dynamics, light interception, and radiation use efficiencyt of selected loblolly pine families," Forest Science, vol. 44, pp. 64-72, 1998. 


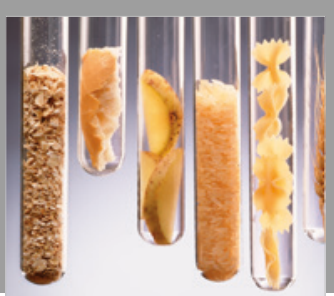

International Journal of Food Science

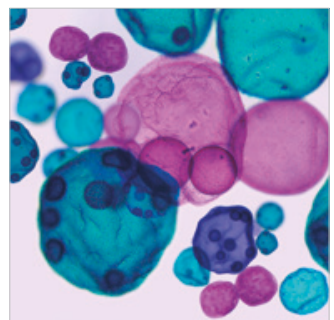

International Journal of Microbiology
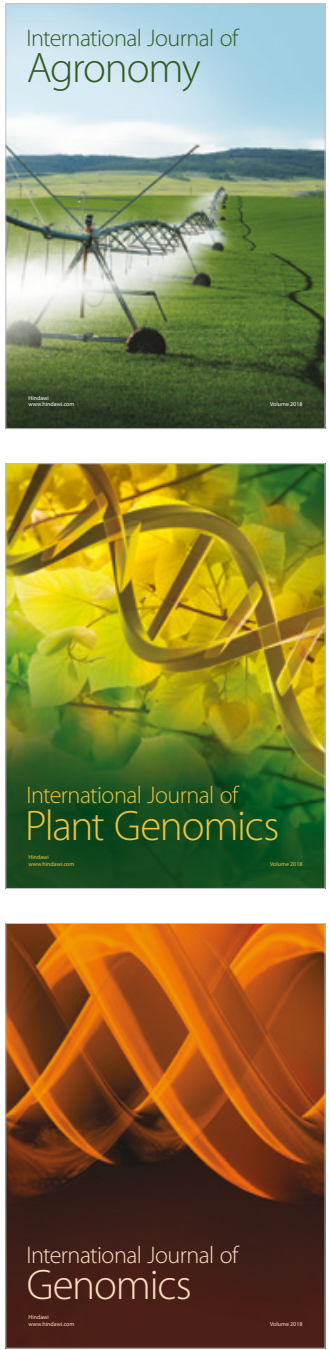

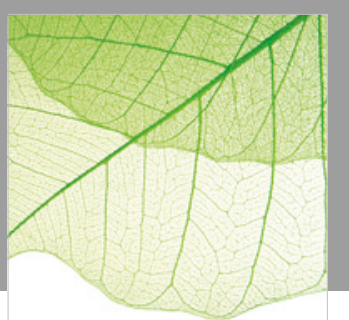

Journal of Botany
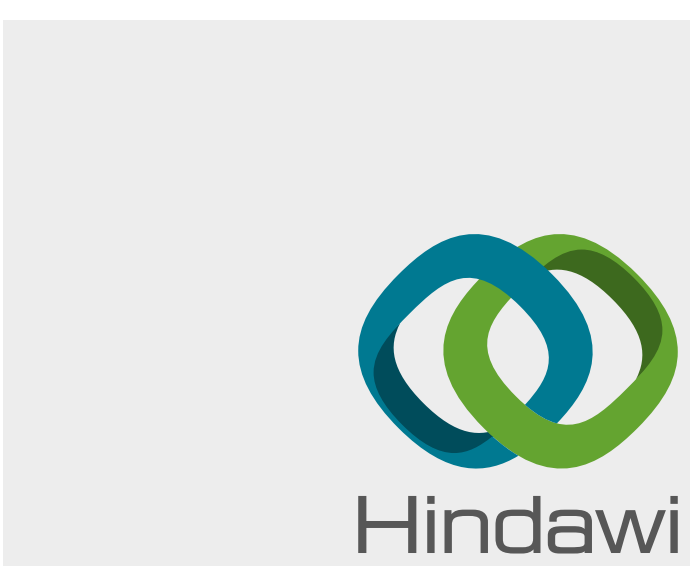

Submit your manuscripts at

www.hindawi.com
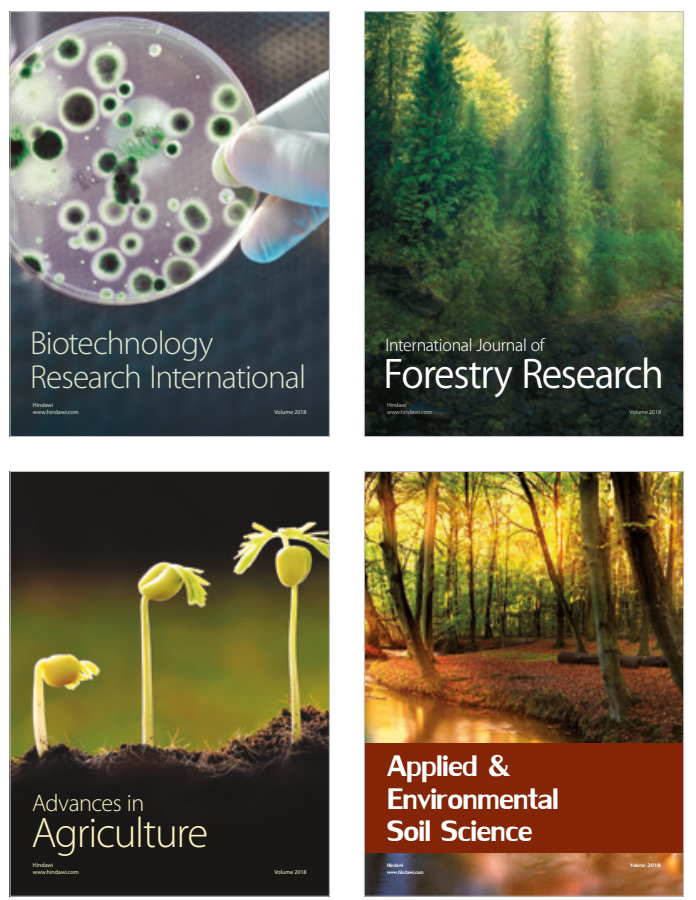

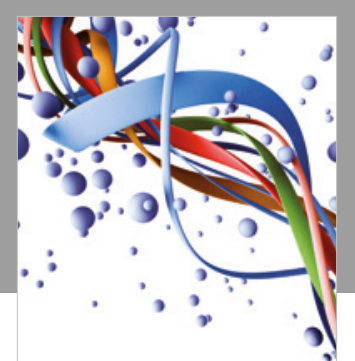

Scientifica

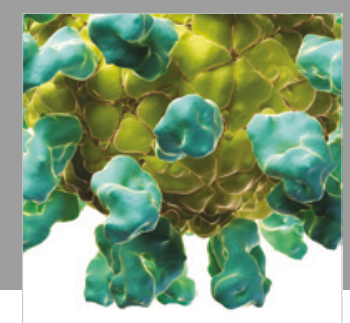

Veterinary Medicine International

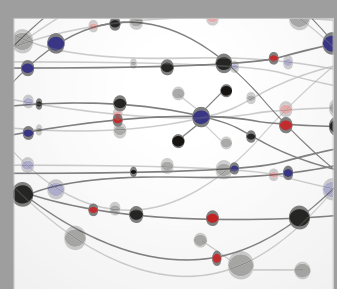

The Scientific World Journal
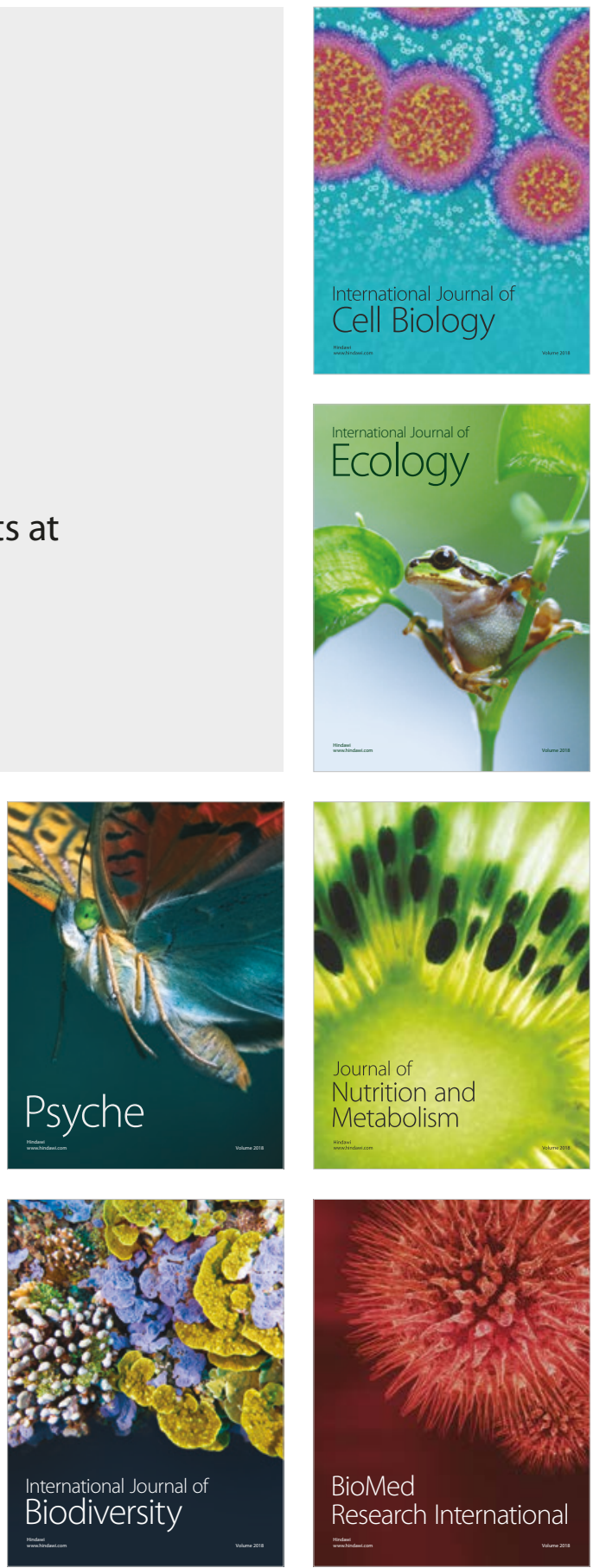